ISSN: 2146-3042

DOI: $10.25095 /$ mufad.843155

\title{
Kurumsal Yönetim İlkelerine Uyum Dereceleri İle Firma Karlılığı Arasındaki İlişki: BIST Kurumsal Yönetim Endeksi (XKURY) Bankacılık Ve Sanayi Sektöründe Faaliyet Gösteren Firmaların Karşılaştırmalı Analizi*
}

\author{
Ali ALAGÖZ ** \\ Hüseyin Enes ERKOÇAK ${ }^{* * *}$
}

\section{ÖZET}

Bu çalı̧̧manın amacı, Borsa İstanbul, Kurumsal Yönetim (XKURY) Endeksinde yer alan, Bankacllık ve Imalat Sanayi sektöründe faaliyet gösteren şirketlerin, kurumsal yönetim ilkelerine uyum dereceleri ile şirket karlılıkları arasındaki ilişkileri ölçmektir. Her iki sektör için elde edilen sonuçlar, karşılaştırmalı analize tabi tutularak, tespitlerde bulunulacaktır. Araştırma 2010-2019 yılları arasındaki 10 ylllık süreyi kapsamaktadır. Ilgili dönemlerde, bankalara ve sanayi firmalarına ait 3' er ayllk finansal veriler, panel veri analiz yöntemi kullanılarak test edilmiştir. Ampirik sonuçlar, sanayi sektöründe uygulanan kurumsal yönetim ilkelerinin, bankacıllk sektörüne göre, karlllık oranları üzerinde daha anlamlı sonuçlar verdiğini ve istatistiksel olarak daha güçlü bir iliş̧ki olduğunu göstermektedir.

Anahtar Kelimeler: Kurumsal yönetim, firma karlllı̆̆l, panel veri analizi.

JEL Sinıflandırması: G30, M10.

The Relationship Between Corporate Governance Principles Compliance Degrees and Company Profitability: BIST Corporate Governance Index (XKURY) Comporative Analysis of Companies Operating in The Banking and Industrial Sector

ABSTRACT

The aim of this study is to measure the relationship between corporate governance principles and company profitability of companies operating in the Banking and Manufacturing Industry sector, included in the Borsa Istanbul Corporate Governance (XKURY) Index. The results obtained for both sectors will be subjected to comparative analysis and determinations will be made. The research covers the 10-year period between 20102019. In the relevant periods, 3-month financial data of banks and industrial companies have been tested using the panel data analysis method. Empirical results show that corporate governance principles applied in the industrial sector give more meaningful results on profitability rates compared to the banking sector and there is a statistically stronger relationship.

Keywords: Corporate Governance, Company Profitability, Panel Data Analysis.

Jel Classification: G30, M10.

\footnotetext{
* Makale Gönderim Tarihi: 25.12.2020, Makale Kabul Tarihi: 16.03.2021 , Makale Türü: Nicel Araştırma

** Prof. Dr., Selçuk Üniversitesi, İktisadi ve İdari Bilimler Fakültesi, aalagoz@selcuk.edu.tr, Orcid ID: 00000003-3873-1936.

*** Selçuk Üniversitesi, İktisadi ve İdari Bilimler Fakültesi, erkocakenes@gmail.com, Orcid ID: 0000-00027648-2793.
} 


\section{GíRiș}

Son yıllarda yaşanan ekonomik krizler, diğer sektörlerde olduğu gibi, finansal sistemin temelini oluşturan Türk bankacılık sektörünü de derinden etkilemiştir. Meydana gelen krizlerin üstesinden gelebilmek ve kalıcı bir çözüm üretebilmek için 2001 yılında uygulanan Güçlü Ekonomiye Geçiş Programı kapsamında Türk Bankacılık Sektöründe Yeniden Yapılandırma Programı uygulamaya konulmuştur. Uygulanan bu program ile, ekonomik büyüme stratejileri, yapısal yenilenmeler, faiz ve kambiyo politikaları gibi bankacılık sistemlerinde yeni reformlar hayata geçirilmiştir. Türk bankacıllk sektörü bu yasal düzenlemeler sayesinde sağlam bir zeminde büyümektedir. Hisseleri borsa da işlem gören bankalar, bir yandan uyguladığı finans politikaları sayesinde karlılığını artırarak, daha yüksek temettü ödemesi ve daha yüksek sermaye kazancı sağlamak suretiyle, mevcut hissedarlarını tatmin etmek istemekte, diğer yandan ise; sermaye yapısını güçlendirmek için hissedar olarak yeni yatırımcıları çekmeyi arzulamaktadır. Yatırımcılar ise; borsada işlem gören bankaların sermayelerine ortak olmak istediklerinde, bankaların, mevcut finansal durumunun yanında, geçmiş dönem finansal başarılarını, sermaye yapısını, yatırım planlarını, ortaklık yapılarını ve yönetimdeki kişilerin etkinlikleri gibi hususlarını da değerlendirmektedirler. $\mathrm{Bu}$ nedenle, bankacılık sektöründe faaliyet gösteren şirketlerin, güçlü bir finansal yapının yanında, yeterli ölçüde güvenilirliğe de sahip olmaları gerekmektedir.

Yatırımcılara karşı şirket imajının olumlu olabilmesi için, bankaların; yatırımcılara ve hissedarlarına karşı sorumluluklarını yerine getirmesi, adil davranması, şeffaf olması, aldığı kararlar ve uyguladığı politikalar karşısında hesap verebilmesi gerekmektedir. Bu noktada; diğer sektörlerde faaliyetlerini sürdüren firmalarda olduğu gibi bankacılık sektöründe yer alan şirketlerinde kurumsal yönetim ilkelerini benimsemesi ve sağlıklı bir şekilde uygulaması önem arz etmektedir. Bankaların, yatırımcıların güveninin kazanılması ve sürdürülebilir finansal büyümenin sağlanması için son yıllarda, kurumsal yönetim ilkelerine daha fazla uyum gösterme çabası içerisine girdikleri görülmektedir. Kurumsal yönetim uygulamalarının, bankalara getireceği ek maliyet ve iş yüküne rağmen, şirket karlılığına olumlu katkı sağlaması beklenmektedir.

Ülkelerin gelişmişlik düzeylerini etkilemeleri açısından, finansal sistemin temeli olan bankacılık sektörünün önemi kadar, imalat sanayinin de kalkınmadaki katma değeri yadsınamaz bir gerçektir.

İmalat sanayi; ülkelerin, üretim güçlerini artırabilmeleri ve refah seviyelerini yükseltebilmeleri için, en fazla önem verdikleri sektörlerin başında gelmektedir. OECD tarafından 2001 yılında yayınlanan rapora göre; imalat sanayi, sektörel bazda, endüstri alanındaki üretkenlik ve verimlilik artışının temel unsuru ve yön vericisi olarak nitelendirilmiştir. Raporda, ülkelerin, üretim gücüne olan katkısı, sağladığı istihdam hacmi, yerli ve yabancı yatırımlar açısından da ekonomiyi en iyi temsil eden sektörlerin başında geldiği belirtilmiştir. Ayrıca; imalat sektörünün, diğer sektörlerin büyümesine ve gelişmesine de öncülük etmesi sebebiyle, ekonomik büyümenin lokomotifi olduğu kabul edilmektedir (Tunç, 2007: 64). 
Bu çerçevede, çalışmanın amacı; Borsa İstanbul, Kurumsal Yönetim Endeksinde yer alan, Bankacılık ve İmalat sektöründe faaliyet gösteren şirketlerin, kurumsal yönetim ilkeleri ile şirket karlılığı arasındaki ilişkileri inceleyerek, her iki sektörü karşılaştırmalı analize tabi tutmaktır.

\section{KURUMSAL YÖNETIMM İLKELERİ VE ENDEKSİ}

Son yıllarda ulusal ve küresel bazda yaşanan finansal krizler ve işletmelerin muhasebe raporlarını manipüle etmesinden kaynaklanan firma skandalları, yatırımcıların, firmalara olan güvenlerini azaltmıştır. Bu nedenle, işletmeler açısından; yatırımcı güveninin yeniden kazanılabilmesi için, kurumsal yönetim kavramı ortaya çıkmıştır.

Kurumsal yönetim; şirket yönetimleri ile şirketlerin uyguladığı finansal politikalar arasındaki uyuşmazlıklardan meydana gelen ve şirket performansını olumsuz etkileyen sorunların, çözülmesini destekleyen bir mekanizmadır (Sloan, 2001:341-342). Ekonomik İşbirliği ve Kalkınma Örgütü (OECD) tanımına göre, kurumsal yönetim; şirket yönetimi, yönetim kurulu ve şirketin hissedarları arasındaki ilişkileri kapsamakta ve şirketin hedeflerine ulaşmasına yardımcı olmaktadır (Davies, 2006: 3). Başka bir ifadeyle, kurumsal yönetim; işletmelere, çeşitli enstrümanlar aracılığıyla fon sağlayan yatırımcıların, yatırımları karşılığında, kazanç sağlayabilmeleri için, şirketler tarafindan uyulması gereken kural, yöntem ve uygulamalardır (Shleifer ve Vishny 1997).

Şirket performansının geliştirilmesi ve şirket yönetimiyle, hissedarlar arasındaki uyumun sağlanması hususlarını esas alan kurumsal yönetimin temel amaçları şu şekildedir (Sönmez ve Toksoy, 2011:58).

-Şirket yöneticilerinin kullandıkları yetki ve sorumlulukların, kendi çıkarları doğrultusunda kötüye kullanılmasını engellemek,

•Yönetimde şeffaflı̆̆ı sağlamak,

•Hissedar ve yöneticilerin karşılıklı yükümlülüklerini belirlemek,

•Yerli ve yabancı yatırımcıların güvenliğini sağlamak,

•Eşitlik ilkesi uyarınca azınlık hisselere sahip hissedarların haklarını korumak,

•Şirket yönetim kurulunun sorumluluklarını belirlemek,

•Vekalet maliyetlerini düşürmek,

•Şirket performansını, dolayısıyla şirketin büyüme ve karlılığını sürdürmektir.

Kurumsal yönetim ilkelerinin şirketlere sağlayacağı faydalardan bazıları; likiditenin yüksek olması, krizlerin kolay atlatılması, finansman firsatlarının bol olması ve düşük sermaye maliyeti olarak sıralanabilir. Kurumsal yönetim uygulamalarının sağladığı bu firsatlar sayesinde, şirketler sermaye piyasalarına daha kolay girebilmektedir (Dağlı vd, 2010:19). Ayrıca, şirketlerde kurumsal yönetim kalitesinin yüksek olması, şirket faaliyetlerini, dolayısıyla hisse senedi değerlerini de yükseltebilmektedir (Gürbüz ve Ergincan, 2004:1). 
Kurumsal yönetim uygulamalarının etkili uygulanmasının şirketlere sağlayacağı faydaların yanında, ülke ekonomilerine de önemli ölçüde katkıları bulunmaktadır. Bunlar; ülke imajının artması, dolayısıyla; yabancı yatırımların ve yabancı sermayenin yükselmesi, sermaye piyasalarının gelişmesi, sermaye piyasalarındaki rekabetin artması, ülke açısından makroekonomik gelişme kaynaklı krizlerin daha düşük kayıplarla atlatılması ve sürdürülebilir finansal derinliğin sağlanması olarak sıralanabilir (Yenice ve Dölen, 2013:200).

Kurumsal yönetimi oluşturan ilkeler temel olarak; hesap verebilirlik, şeffaflık, eşitlik ve sorumluluk ilkeleridir.

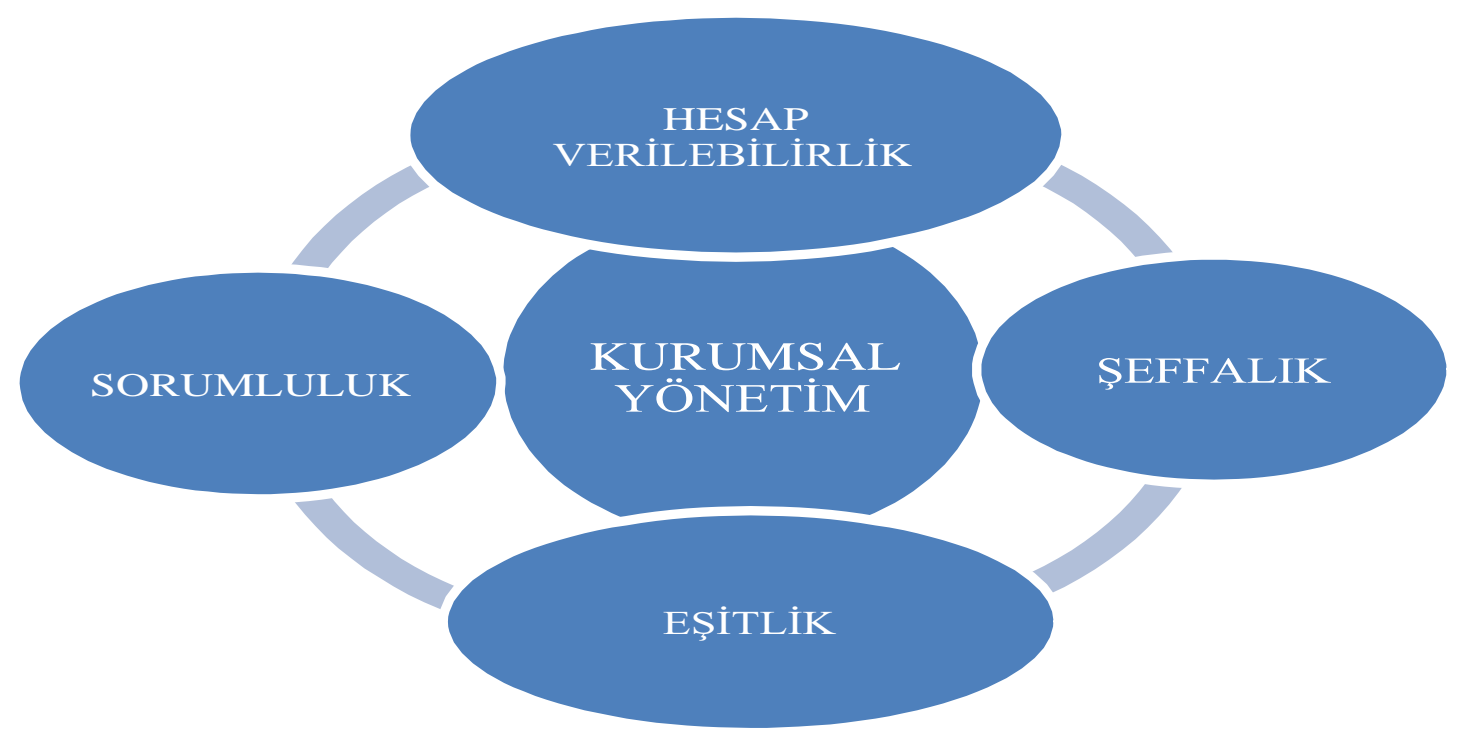

Șekil 1. Kurumsal Yönetim İlkeleri

Hesap Verebilirlik İlkesi: Pay sahiplerinin bazı hakları kurumsal yönetim ilkeleri açısından korunmalıdır. Bu haklar, arasında; genel kurul toplantılarına katılma ve oy kullanma, düzenli olarak şirket hakkında açıklayıcı bilgilere ulaşma, şirketin faaliyetlerinden elde ettiği kar' dan pay alma, rüçhan hakkı, şirket ile ilgili alınacak önemli kararlarda söz alabilme ve bilgilendirilme, gibi haklar bulunmaktadır (Topaç, 2002: 17).

Şeffaflık İlkesi: : Kamuyu aydınlatma ilkesi olarak ta isimlendirilebilir. Şeffaflık ilkesi temel olarak, şirketin mevcut finansal yapısı ve durumunun, kurumsal yönetim uygulamaları ile bilgilerin kamuoyuna aktarılmasıdır. Şeffaflık ilkesi, şirket hisselerinin çoğunluğuna sahip olan hissedarlar ile diğer pay sahipleri arasındaki asimetrik bilgi sorununu çözmek için uygulanan önemli bir kurumsal yönetim ilkesidir. Hisselerin çoğunluğuna sahip olan hissedarlar, şirketin finansal politikalarına ve mali bilgilerine daha kolay ulaşmakta ve bu bilgileri azınlık paylara sahip ortaklar ile paylaşmayabilmektedir. $\mathrm{Bu}$ nedenle; bilgilerin şeffaflık ilkesi uyarınca kamuoyuna açıklanması hissedarlar arasındaki bu asimetrik bilgi sorununu çözecektir (Ertuna ve Tükel, 2008:10-11). 
Eşitlik İlkesi: Eşitlik ilkesi, yöneticilerinin; şirket faaliyetlerini yerine getirirken almış olduklar kararları, tüm hissedarlarına karşı eşit ve aynı zamanda paylaşılmasıdır. Ayrıca, şirket tarafindan, hissedar grupları arasında herhangi bir tarafa menfaat sağlayacak şekilde bilgi aktarımı vesilesiyle, hak ihlali olması durumunda, hissedarların bu ihlal karşısında tazmin gücü bulunması gerekmektedir (Uyar, 2004:8).

Sorumluluk İlkesi: Sorululuk ilkesi, şirket yönetim kurulunun ve yöneticilerin aldıkları karar ve eylemler ile yaptıkları tüm faaliyetlerin şirket içi düzenlemelere, mevzuata ve toplumsal etiklere uygunluğunu ifade etmektedir.

Sorumluluk ilkesi gereğince, yöneticilerin şirket faaliyetleriyle ilgili alınan karar süreçlerinde, tüm hissedarların menfaatlerini ön planda tutmaları ve hissedarlarla işbirliği içerisinde olmaları gerekmektedir. Ayrıca, yöneticilerin; hissedarlar, çalışanlar, müşteriler ve tedarikçiler gibi ilişkili bulunanların menfaatlerini azami derecede yerine getirebilme endişesini taşıması gerekmektedir (Pasl1, 2008:57).

Kurumsal yönetim uygulamaları ile ilgili, gelişmiş ve Türkiye gibi gelişmekte olan pek çok ülkede, son dönemlerde mevzuat düzenlemelerine başlanılmıştır. Bu düzenlemeler, İngiltere de 1992 de Cadbury ve 1995 te Greenbury kodları ile, Amerika da ise 2002 senesinde Sarbanes Oxley yasası ile faaliyete girmiştir. Son olarak, bu ilkelerin dünya genelinde yaygınlaşması amacıyla, 2004 yılında OECD raporu yayınlanmıştır. Kurumsal yönetim performans derecelendirmeleri, Japonya, Kore, Tayvan, Filipinler gibi gelişmiş ve gelişmekte olan ülkelerde ise, faaliyete giren kurumsal yönetim kuruluşları tarafından gerçekleştirilmektedir (Chang ve diğerleri 2015). Türkiye de ise Sermaye Piyasası Kurulu (SPK) tarafından 2003 te yayınlanan ilkeler doğrultusunda, kurumsal yönetim ilkelerini uygulayan şirketlerin performanslarını ölçmek için, 2007 de Borsa İstanbul, Kurumsal Yönetim Endeksi (XKURY) kurulmuştur. BIST çatısı altında hesaplanan Kurumsal Yönetim Endeksi, hisseleri bu endekste işlem gören ve kurumsal yönetim ilkelerine ait derece notu alan halka açık şirketlerden oluşmaktadır. Kurumsal Yönetim Endeksinin amacı; bu endekste işlem gören ve kurumsal yönetim uyum notu 10 üzerinden en az 7 ve her bir ana başlık için 6,5 olan şirketlere ait fiyat ve getiri performanslarının ölçülmesidir. Uyum notları, SPK tarafından belirlenen derecelendirme kuruluşları tarafından, şirketlerin; kurumsal yönetim ilkelerine uyumlarına ilişkin yapılacak değerlendirmeler sonucuna göre verilmektedir. $\mathrm{Bu}$ endekste işlem görmek isteyen şirketler de yine, SPK tarafindan lisanslandırılan kuruluşlarca derecelendirilerek Borsa İstanbul'a bildirilir. Derecelendirme kuruluşları, şirketleri derecelendirirken, pay sahipleri (\%25), kamuyu aydınlatma ve şeffaflık (\%25), menfaat sahipleri (\%15) ve yönetim kurulu (\%35), olmak üzere dört ana başlık üzerinden değerlendirmekte ve derecelendirmeleri belirlenen oranlara göre gerçekleştirmektedir (TKYD).

\subsection{Bankacılık Sektörü ve Kurumsal Yönetim}

Finansal sistemin temeli olan bankacılık sektörü, finansal yapısı itibariyle, diğer sektörlere nazaran çok daha farklı özellikler barındırmaktadır. Bankacılık dışındaki piyasalarda alış veriş yapan kişiler, paralarını, hemen o anda bir ürün veya hizmete sahip olabilmek için harcamaktadırlar. Ancak, bankacılık sektöründe işlem gerçekleştiren yatırımcılar, mevduatlarını gelecek bir zamanda kazanç elde edebilmek için bankalara yatırmaktadırlar. Yine ürün ve hizmet piyasalarındaki müşteriler; satın aldıkları bir ürün 
bozuksa veya beklenti ve taleplerine cevap veremiyorsa bu durumun anında farkına varırken, bankalara yatırılan paranın, nasıl değerlendirileceği gözlenemeyebilir ve müşteriler mevduatları karşılığında, kar beklerken, zararla karşılaşabilir (Caprio, Levine, 2002:11). Finansal piyasalarda yerine getirdiği görevler itibariyle bankacılık sektörü, ülke ekonomileri ve finansal piyasalar açısından hayati öneme sahiptir. Özellikle kısa vadeli fon sağlayanlar ile fon talep edenleri buluşturan bankalar, mevduat toplama, kredi kullandırma, toplanan sermayeyi tabana yayma ve risk çeşitlendirme gibi faaliyetleri gerçekleştirmektedir. Ancak, gerçekleştirdiği faaliyetler sonucu ülke kalkınmasına önemli katkıda bulunan bu sektör, işlemleri nedeniyle barındırdığı sistematik riskler sayesinde, ekonomik kriz üretecek kadar önemli bir potansiyele de sahiptir (Arıkan, 2008: 50). Bu nedenle; diğer sektörlerde olduğu gibi bankacılık sektöründe de kurumsal yönetim ilkelerinin uygulanması büyük önem arz etmektedir.

Özellikle gelişmekte olan ekonomiye sahip ülkelerde, kurumsal yönetimin bankacılık sektöründeki önemini daha da arttıran çeşitli etkenler mevcuttur. Bunlardan birisi; bankacılık sektörünün, gelişmekte olan ekonomilerde, finansal sistemin ve ekonomik büyümenin temelini oluşturmasıdır. Diğer bir etken, gelişmekte olan ekonomiler de finansal piyasalar düşük gelişmişlik düzeyine sahip olduğu için, işletmeler için finansman kaynağı bankalardır. Başka bir etken, bu ülkelerde faaliyet gösteren bankalar, hem; ödeme araçlarını kullandırmakta, hem de; ekonomideki tasarruflar için merkezi depo görevini üstlenmektedir. Son bir etken ise; gelişmekte olan ülkelerin bankacılık sektörlerinde özelleştirme ve çeşitli yasal düzenlemelerle sağlanan liberilizasyonun, kurumsal yönetimin önemini arttırdığı düşünülmektedir. Çünkü bu durum, banka yöneticilerin, kurumlarını yönetirken daha özgür davranış sergilemelerine izin vermektedir ( Arun ve Turner, 2004:372).

Bankalar; kurumsal yönetim uygulamalarına ilişkin düzenlemeler de Basel Bankacılık Komitesi tarafindan belirlenen kural ve ilkeleri temel almaktadırlar. Basel Bankacılık Komitesi, bankalarda kurumsal yönetimi; gerçekleştirilen faaliyetlerin yönetim kurulu ve üst yönetimlerce, idare edildiği bir yapı olarak tanımlamakta ve kurumsal yönetim yapısından, banka yönetim kurulu ve üst yönetimin sorumlu olduğunu belirtmektedir. Kurumsal yönetim yapısı, en başta bankanın hissedarları olmak üzere, bankaya kaynak sağlayan mevduat sahipleri, kreditörler ve banka çalışanlarını doğrudan etkilemektedir. $\mathrm{Bu}$ nedenle; Basel komitesi; bankalarda, rüşvet ve yozlaşmanın önlenmesi, hissedar haklarının korunması, yöneticiler, çalışanlar ve hissedarların haklarının düzenlenmesi gibi teşvik edici tedbirleri önermektedir. Basel Bankacılık Komitesine göre; kurumsal yönetim yapısı aşağıdaki yaklaşımları etkilemektedir (BIS, 2006:4).

-Kurumsal hedeflerin belirlenmesi,

•Günlük faaliyetlerin yürütülmesi,

•Pay sahiplerine karşı olan hesap verme sorumluluğunun yerine getirilmesi ve diğer yatırımcıların menfaatlerinin gözetilmesi,

-Mevduat sahiplerinin çıkarlarının korunması, 


\section{2. İmalat Sanayi Sektörü ve Kurumsal Yönetim}

İmalat sanayi, sanayi sektöründe faaliyet gösteren en önemli ve dinamik sektördür. İmalat sanayi, neredeyse tüm ülkelerde, yarattığı üretim miktarı ve sağladığı istihdam açısından en büyük paya sahiptir. Üç önemli alt birimi bulunan imalat sanayi sektörünün ilk bölümü; gıda, dokuma, tütün, hazır giyim, mobilya, gibi tüketim mallarından oluşmaktadır. Diğer bir bölümü; kağıt, plastik, petrol ürünleri, kimya, çimento, seramik, demir, cam, çelik ve metaller gibi ara mallardan oluşmaktadır. Son bölümü ise; madeni eşya, elektrikli makinalar, kara yolu taşıtları, demiryolu taşıtları, gemi ve uçak imalatı gibi, yatırım mallarından oluşmaktadır (Karluk, 2002:65).

Türkiye'de başlıca tüm sanayi kolları, imalat sanayi ve alt sektörleri olup imalat sanayi,

- Dayanıklı tüketim malları olan; gıda, dokuma, kimya, giyim eşyası, makine teçhizat gibi birçok ürünün üretildiği sanayi koludur.

- İmalat sanayi esas itibariyle sanayinin temeli sayılır,

- İmalat sanayi, diğer sanayi kollarına göre daha yüksek istihdam oranına sahiptir,

- İhraç edilen ürünlerin başında imalat sanayi ürünleri gelmekte olup, ülke ekonomisi için büyük önem arz etmektedir (Koç vd. 2018:20).

İmalat sanayi, ülkelerin gelişmişlik düzeylerinin en temel göstergesidir. Ülke ekonomileri geliştikçe, farklı sektörlerin ekonomi içindeki payları da değişime maruz kalmaktadır. Önceki dönemlerde, tarım gibi doğal kaynaklara dayalı sektörler ekonomi içinde önemli bir paya sahipken, ülkeler gelişim gösterdikçe, bu pay yerini imalat sektörüne bırakmaktadır (TÜSİAD, 2008:37). Gelişmiş ve gelişmekte olan ülkelerde, ekonomik büyüklüğün temel göstergesi olan gayri safi yurt içi hasılanın önemli bir kısmını teşkil eden imalat sanayi sektörü, ülke ekonomileri için hayati öneme sahiptir. Bu nedenle; bankacıllk sektöründe ve diğer sektörlerde olduğu gibi imalat sanayi sektöründe de kurumsal yönetim ilkelerinin uygulanması büyük önem arz etmektedir.

\section{LITERATÜR}

Ulusal ve uluslararası literatürde, bankacılık sektöründeki kurumsal yönetim uygulamaları ile şirket performansı arasındaki ilişkileri tespit etmek için birçok çalışma yapılmıştır. Bunlardan bazıları aşağıdaki gibidir.

Tanrı̈̈ven vd (2006), çalışmalarında; İMKB de işlem gören ticari bankalarda kurumsal yönetimin firma performansına etkilerini araştırmışlardır. Çalışmada, bankaların sahiplik yapısı ve kontrolünün banka performans ölçümünde kullanılan oranlarla ilişkisi Varyans analizi tekniği ile incelenmiştir. Bulgular, aile ve holding bankacilığı arasında önemli farlılık olmadığı, ancak; dağınık sermayeli ve kontrolü olan bankaların diğer bankalardan farklılaştı̆̆ı yönündedir. Ghayad (2008), çalışmasında; Bahreyn'de faaliyet gösteren İslami bankaların performansının finansal rasyolar gibi sadece sayısal değişkenlerden değil, aynı zamanda 
yönetimle ilgili değişkenlerden de etkilendiğini tespit etmiştir. Aebi vd. (2008), çalışmalarında ABD bankalarını, finansal kriz döneminde incelemiş, banka performansları ile bazı kurumsal yönetim değişkenleri arasında anlamlı bir ilişki bulunmadığı, bazıları ile de anlamlı ve negatif bir ilişki olduğu sonuçlarına ulaşılmıştır. Cornett vd. (2009), çalışmalarında; Amerika' da faaliyet gösteren en büyük bankalarda kurumsal yönetim uygulamalarının kazanç yönetimine etkisi araştırılmıştır. Bulgulara göre; bankaların net temettü oranı, borç/öz sermaye oranı, fiyat-kazanç oranı, yabancı ortak oranları ile Tobin Q değeri arasında pozitif bir ilişki olduğu sonucuna ulaşılmıştır. Aygün vd (2010), çalışmalarında; İMKB işlem gören 12 bankanın 2006-2008 yılları arasındaki kurumsal yönetim uygulamalarıyla banka performansı arasındaki ilişkiyi Regresyon ve Korelasyon analizi yöntemi kullanarak test etmiştir. Regresyon sonuçlarına göre; yönetim kurulu büyüklüğü ile piyasa değeri arasında anlamlı ve pozitif bir ilişki olduğu, yönetim kurulunun büyüklüğü ile karlılık arasında ise; anlamlı ve negatif bir ilişki olduğu sonuçlarına ulaşmışlardır. Grove vd. (2011), Amerika’ da ki 236 bankanın 20052008 yılları arasında ve 2008 finansal krizinde, çeşitli kurumsal yönetim uygulamalarının bankaların finansal performanslarına etkisi olduğu sonucuna ulaşmışlardır. Arouri vd. (2011), çalışmalarında; Körfez ülkelerinde yer alan 27 bankayı 2008 yılı için analiz etmişlerdir. Çalışmanın bulgularına göre; banka performansı ile sahiplik yapısı arasında güçlü bir ilişki olduğu, ancak; diğer kurumsal yönetim ilkeleriyle banka performansı arasında anlamlı bir ilişki olmadığı sonuçlarına ulaşılmıştır. Akhyar vd. (2011), çalışmalarında Malezya da yer alan bankaların kurumsal yönetim uygulamalarının banka etkinlikleri üzerindeki etkisini panel veri analizi yöntemiyle araştırmışlardır. Yapılan ekonometrik analiz bulgularına göre; kurumsal yönetim ile banka etkililiği arasında olumlu bir ilişki bulunmuştur. Ayrıca; özellikle bağımsız ve küçük olarak oluşturulan yönetim kurullarının banka etkinliklerini olumlu etkiledikleri tespit edilmiştir. Beycan (2013) çalışmasında, Borsa İstanbul da işlem gören, 20 bankayı panel veri analizi uygulayarak incelemiştir. Bulgulara göre; halka açıklık oranı, yönetim kurulu üye sayısı ve toplantı sayısı ile aktif karlılık arasında pozitif, en büyük üç hissedarın payı ile aktif karlılık arasında negatif, Özsermaye karlılığı ile bağımsız üye sayısı arasında pozitif, varlık kalitesi ile yönetim kurulu üye sayısı, bağımsız üye sayısı, en büyük üç hissedarın payı ile pozitif, yönetim kurulu toplantı sayısı ile negatif bir ilişki tespit etmiştir. Peni ve Vahamaa (2012), çalışmalarında; 2005-2008 yılları arasında Amerika’da faaliyet gösteren 62 bankanın verilerini kullanarak, 2008 finansal krizini dikkate aldıkları araştırmaya göre; kurumsal yönetim uygulamaları ile banka performansları arasında hem olumlu, hem de olumsuz etkileri olduğu sonuçlarına ulaşılmıştır. Onakoya vd. (2012), çalışmalarında; Nijerya Borsası'nda 2005-2009 yılları arasında işlem gören 6 adet bankanın verileriyle zaman serileri yöntemiyle incelemişlerdir. Sonuç olarak; kurumsal yönetim uygulamalarının zayıflamasının, bankaların performansını da düşürdüğünü tespit edilmiştir. Dinçer ve Dinçer (2013), çalışmalarında; BIST' te işlem gören bankalarda, kurumsal yönetim uygulamaları ile firma performansı arasındaki ilişkiyi analiz etmişlerdir. Bulgulara göre; kurumsallaşma derecesi yüksek olan bankaların hisse senedi fiyatlarının ise düşük risk düzeyi sebebiyle düşük olduğu, kurumsallaşma derecesi düşük olan bankaların hisse senedi fiyatlarının ise, daha yüksek olan risk düzeyi nedeniyle yüksek olduğu tespit edilmiştir. Fanta vd. (2013) çalışmalarında; 20052011 yılları arasında Etiyopya da faaliyet gösteren ticari bankalar üzerinde yaptığı araştırmaya göre; kurumsal yönetim düzeyinin banka performansını etkilediği sonucuna ulaşmıştır. Bulgulara göre; yönetim kurulu büyüklüğü ve yönetimde denetim kurulunun bulunmasıyla banka performansı arasında anlamlı ve negatif bir ilişki olduğu, banka büyüklüğü ve kurumsal 
yönetim ölçüsü olarak sermaye yeterlilik oranının ise banka performansı üzerinde pozitif etkisinin olduğu sonuçlarına ulaşılmıştır. Kandır (2013), çalışmasında; BIST kurumsal yönetim endeksinde işlem gören 6 bankanın, 2011 yılı kurumsal yönetim derecelendirme notunun, hisse senedi getirileri üzerindeki etkisini Event Study ( Olay çalışması) yöntemini kullanarak 5 günlük olay penceresinde incelemiştir. Çalışma bulgularında, kurumsal yönetim derecelendirme notunun, hisse senedi getirilerine önemli bir etkisinin olmadığı sonucuna ulaşılmıştır. Kula ve Baykut (2013), çalışmalarında; mevduat bankalarının, Kurumsal Yönetim Endeksi'nde yer almalarının finansal performanslarına olan etkisini, panel veri analizi yöntemiyle test etmişlerdir. Çalışmada BIST' te işlem gören ve 5' i Kurumsal Yönetim Endeksinde yer alan, toplam 14 ticari bankanın 2007-2012 arasındaki verileri kullanılmıştır. Bulgular; kurumsal yönetim endeksinde yer almak ile piyasa değeri arasında istatistiksel olarak anlamlı bir ilişki olmadığı yönündedir. Ayrıca; bahse konu bankaların, piyasa değeri ile mevduat büyüklüğü arasında negatif bir ilişki olduğu ve piyasa değeriyle, aktif karlılığı ve özsermaye büyüklüğü arasında ise pozitif bir ilişki olduğu sonuçlarına ulaşılmıştır. Shungu vd. (2014), çalışmalarında; Zimbabve' de faaliyet gösteren ticari bankaların 2009-2012 yılları arasındaki dönemlerde, bazı kurumsal yönetim ilkeleriyle, banka performansı arasında anlamlı ve pozitif; bazı kurumsal yönetim ilkeleriyle, banka performansları arasında ise anlamlı, fakat; negatif bir ilişki olduğu sonuçlarına ulaşmışlardır. Bukair ve Rahman (2015), çalışmalarında; Körfez ülkelerinde faaliyet gösteren 40 İslami bankanın 2008-2011 yılları arasındaki kurumsal yönetim ilkeleriyle performansları arasındaki ilişkileri araştırmışlardır. Analiz sonuçlarına göre, farklı kurumsal yönetim ilkeleriyle banka performansları arasında farklı sonuçlar tespit edilmiştir. Bu sonuçlar; yönetim kurulu büyüklüğüyle banka performansı arasında olumsuz bir ilişki olduğu, CEO ve yönetim kurulu başkanın farklı kişiler olmasının banka performansını etkilemediği ve yönetim kurulu başkanının üst yönetimden bağımsız olmasının banka performansını olumlu etkilediği şeklindedir. Naushad ve Malik (2015), çalışmalarında; Körfez ülkelerinde faaliyet gösteren 24 bankanın 2012-2013 verilerini incelemişlerdir. Araştırma bulguları, kurumsal yönetim uygulamalarının, bankaların finansal performanslarını önemli ölçüde etkilediği şeklindedir. Manini ve Abdillahi (2015), çalışmalarında; 2014 yılında Kenya'da faaliyet gösteren bankaları incelemişlerdir. Sonuç olarak, tüm kurumsal yönetim uygulamalarının önemli olmamasına karşın, etkili kurumsal yönetim uygulamaları ile bankaların finansal performanslarının iyileştirilebileceği tespit edilmiştir. Lee ve Isa (2015), çalışmalarında; Malezya da faaliyet gösteren bankaların 20032011 yılları arasında; kurumsal yönetim uygulamaları ile banka performansları arasındaki ilişkiyi araştırmışlardır. Çalışmada yönetim kurulu üyelerine verilen ücret ile banka performansı arasında pozitif bir ilişki olduğu sonucuna ulaşılmıştır. Ayrıca; ücretlendirme ile yönetim kurulundaki bağımsız üye oranı arasında pozitif, fakat; yönetim kurulu büyüklüğü ile negatif bir ilişki olduğu tespit edilmiştir. Gümüş vd. (2015) çalışmalarında; Türkiye ve Kazakistan'da faaliyet gösteren bankaların, finansal performans ve kurumsal yönetim uygulamaları arasında anlamlı bir ilişki olduğu sonucuna ulaşmışlardır. Ahmed vd. (2016), çalışmalarında; Bangladeş teki İslami bankaların 2009-2014 dönemi için yaptıkları araştırmaya göre; kurumsal yönetim ve kurumsal yönetim ilkeleri ile banka performansı arasında anlamlı bir ilişkiye rastlayamamışlardır. Kusuma ve Ayurmardani (2016), çalışmalarında 2010- 2014 dönemlerinde, Endonezya da faaliyet gösteren İslami bankaların kurumsal yönetim etkinliği ile banka performansı arasında önemli bir ilişki olduğu sonucuna ulaşmışlardır. Nawaz (2017), çalışmasında; dünya genelinde, 67 İslami bankanın 2006-2009 döneminde, kurumsal yönetim uygulamalarının, banka performansını etkilediği sonucuna ulaşmıştır. Ayrıca, çalışmada; CEO ve yönetim kurulu başkanının aynı kişi olmasının banka 
performansını olumlu etkilediği, danışma kurulunun büyüklügünün ise banka performansını olumsuz etkilediği tespit edilmiştir.

Literatürde, imalat sanayi sektöründeki kurumsal yönetim uygulamaları ile şirket performansı arasındaki ilişkileri tespit etmek için de pek çok çalışma yapılmıştır. Bu çalışmalardan bazıları ise, aşağıdaki gibidir.

Januszewski vd. (1999), 1986-1994 yılları arasındaki verilerin analiz edildiği çalışmalarında Almanya'daki 400 imalat firması ile toplam faktör verimliliği üzerine ampirik bir analiz yapmışlardır. Araştırmalarında, Almanya'daki verimlilik artışının son yıllarda neden AB ülkelerinden, özellikle de Amerikan firmalarından daha yavaş olduğunu incelemişlerdir. Bulgular; bu olayın ana nedenlerinden birisinin zayıf kurumsal yönetim olduğu yönündedir. Ayrıca, bulgularda; Alman imalat firmalarının rekabet düzeylerinin tespiti için sahiplik yapısı ve kurumsal yönetim etkilerinin daha fazla araştırılması gerektiği sonucuna varılmıştır. Yıldırım (2007), BIST’ de işlem gören 44 imalat şirketinin 2002-2006 yılları arasındaki verileriyle, mülkiyet ve yönetim kontrol yapılarının özelliklerinin firmaların performanslarına etkisini araştırmıştır. Bulgularda; mülkiyet ve kontrol yapısı değişkenlerinden olan en büyük hissedarın pay oranı, toplam kontrol oranı, en büyük üç hissedarın pay oranı, genel kurula katılım oranı ve genel kurula hâkimiyet oranı değişkenlerinin, aktif kârlılığı, satışların kârlılığı ve özsermaye kârlılığı ile negatif bir ilişki, pazar değeri ve Tobin Q değeri ile pozitif bir ilişki olduğu sonuçlarına ulaşmıştır. Yıldırım ve Demireli (2009), çalışmalarında, BIST imalat firmalarının sahiplik ve kontrol yapısını değişkenlerini ile firma performans arasındaki ilişkileri araştırmışlardır. Çalışmanın veri setinde, sermaye ve kontrol yapısı ile ilgili olarak en büyük pay sahibinin payı ile en büyük pay sahibinin genel kurula hâkimiyeti değişkenleri ile firma performansını ölçmek için ROA, ROS, ROE ve Tobin’s Q değişkenleri kullanılmıştır. Analiz sonucu; en büyük pay sahibinin payı ile ROA, ROS, ROE arasında negatif bir ilişki olduğu ve Tobin's Q ile ölçülen firma değeri arasında ise, pozitif bir ilişki olduğu şeklindedir. Lin vd. (2009), çalışmalarında; Çin de faaliyet gösteren 461 imalat firmasının 1999-2002 yılları arasında verilerini kullanarak, kurumsal yönetim ile şirket üretkenliği arasında nasıl ve ne ölçüde bir ilişki olduğu, iki aşamalı Veri Zarfı Analizi Yöntemi kullanılarak incelemişlerdir. Bulgulara göre; siyasi müdahalelerin firma performanslarını düşürdüğüne dair güçlü kanıtlara ulaşılmıştır. Al-Haddad vd. (2011), çalışmalarında; Amman borsasında işlem gören imalât firmaları üzerindeki kurumsal yönetimin etkilerini incelemişlerdir. Sonuç olarak, kurumsal yönetim uygulamalarıyla firma performansı arasında pozitif bir ilişki tespit edilmiştir. Elde edilen bu sonucu da, hisse başına kâr ve aktif kârlılık değişkenleri altında incelenen karlılık ile kurumsal yönetim arasındaki pozitif ilişki desteklemektedir. Ayrıca, araştırma bulguları; likidite ve şirketin büyüklüğünün de kurumsal yönetimi pozitif etkilediğini göstermektedir. Memiş ve Çetenak (2012), çalışmalarında; BIST imalat sanayi de işlem gören 118 adet firmanın 2004-2009 yılları arasında ki verilerini düzeltilmiş Jones modeliyle analiz ederek kazanç yönetimi uygulamalarının yönetim yapılarının kurumsallık derecelerinden etkilenip etkilenmediğini araştırmışlardır. Araştırma sonuçları, BIST kurumsal yönetim endeksi, ortaklık konsantrasyonu ve CEO'ların yönetim kurulu başkanlarından bağımsız olmaları ile kazanç yönetimi uygulamaları arasında anlamlı bir ilişki tespit edilemediğini göstermektedir. Zelka (2013), çalışmasında; BIST - XKURY endeksinde işlem gören firmalardan sadece üretim sektöründe faaliyet gösteren 126 işletmenin 2005-2011 
y1lları arasındaki verileri kullanarak kurumsal yönetim uygulamaları ile firma performansları arasındaki ilişkileri araştırmıştır. Çalışmada bağımlı değişken olarak özsermaye karlılığı ve Tobin's Q değerleri, bağımsız değişken olarak ise kurumsal yönetim ilkeleri araştırmaya dahi edilmiştir. Elde edilen bulgular; kurumsal yönetimin firma karlılığı üzerinde anlamlı olmadığ yönündedir. Turan ve Bayyurt (2013), çalışmalarında; imalat sektöründe işlem gören şirketlerin 2008-2011 yılları arasındaki verileriyle, kurumsal yönetim ile firma karlılığ1 arasındaki ilişkileri panel veri analizi yöntemiyle araştırmışlardır. Yönetim kurulu, Denetim Kurulu ve Bağımsız üye sayısının firma performansı ile pozitif, en büyük ortağın payı ve halka açıklık oranı ile firma performansı arasında negatif bir ilişki olduğu sonuçlarına ulaşılmıştır. Acaravcı vd. (2015), 2005-2011 yılları arasında BİST İmalât Sektöründe işlem gören 126 firmanın yıllık verileri kullanıldığı çalışmalarında, kurumsal yönetim ile firma performansı arasında ilişki olduğu tespit edilmiştir. Kayalı ve Doğan (2018), BIST üretim sektöründe faaliyet gösteren firmaların 2012-2016 yılları arasındaki verileri kullanılarak, kurumsal yönetim derecelendirme notu ile finansal performansları arasındaki ilişki Altman, Springate ve Fulmer Skor modelleriyle analiz etmişlerdir. Bulgular, firmaların kurumsal yönetim notlarıyla, finansal başarıları arasında anlamlı bir ilişki olduğu yönündedir.

\section{METODOLOJİ VE VERI}

\subsection{Veri Seti}

Araştırma 2010-2019 arasındaki 10 yıllık süreyi kapsamaktadır. Araştırmaya konu olan firmalar 10 yıllık süre zarfında 3' er aylık çeyrek dönemler itibariyle toplam 40 dönemde verileri yayınlanan, BIST Kurumsal Yönetim Endeksi (XKURY)' de yer alan Bankacılık Sektöründe faaliyet gösteren 4 firmadan (Yapı ve Kredi Bankası A.Ş., Şekerbank, Türkiye Sınai Kalkınma Bankası A.Ş., Albaraka Türk Katılım Bankası A.Ş.) ve İmalat Sanayi Sektöründe faaliyet gösteren 4 firmadan (Otokar Otomotiv ve Savunma Sanayi A.Ş., Tofaş Türk Otomobil Fabrikası A.Ş., Türk Traktör ve Ziraat Makineleri A.Ş. ile Arçelik A.Ş.) oluşmaktadır.

Çalışmada kullanılan veriler bağımlı ve bağımsız veriler olmak üzere iki gruptur. Bağımlı değişken olarak; Kamuoyu Aydınlatma Platformu (KAP) ta yer alan, firmalara ait finansal tablolardan elde edilen, firmaların karlılık etkinliklerini ölçmek için; Hisse Başına Kar (HBK), Aktif Karlılığı (ROA), Özsermaye Karlılığı (ROE) ve Faaliyet Karlılığı Oranı (FKO) değişkenleri kullanılmıştır. Bağımsız değişkenler ise; çalışmada yer alan 8 firmanın Türkiye Kurumsal Yönetim Derneği web sitesinden temin edilen, Kurumsal Yönetim Derecelendirme Puanı, Hesap Verilebilirlik Puanı, Eşitlik Puanı, Şeffaflık Puanı ve Sorumluluk Puanı verilerinden oluşmaktadır.

\subsection{Yöntem}

Ekonometrik uygulamalarda, genel olarak, zaman serisi verileri ve yatay kesit veriler kullanılarak sonuca ulaşılmaktadır. Zaman serilerinin analiz edildiği çalışmalarda, değişkenlerin belirli bir zamandaki değerleri dikkate alınırken, yatay kesit verilerin kullanıldığı çalışmalarda ise; tek bir zaman noktasındaki farklı değişkenler karşılaştırılmaktadır. Zaman serileriyle, yatay kesitlerin birlikte kullanıldığ çalışmalar ise "Panel Veri Analizi" olarak isimlendirilmektedir (Wooldridge, 2009:54). Panel veri analizlerinde yatay kesit ve zaman serisi verilerinin kullanılması ile gözlem sayısı 
çoğalmakta, bu durum ise; serbestlik derecesinin artmasını ve açıklayıcı değişkenler arasındaki yüksek derecede doğrusal ilişki bulunma olasılığını azaltmaktadır. Panel veri analizinin, diğer regresyon modellerine karşı başka üstünlükleri de bulunmaktadır. Sadece yatay kesit verilerinin kullanıldığı çalışmalar; yalnızca, birimler arasındaki farklılıkları açıklarken, panel veri analizi ile incelenen çalışmalar ise hem birimler hem de bir birimde zaman içinde meydana gelen değişimleri açıklayabilmektedir. Ayrıca; panel veri analizi, yatay kesit veya zaman serileri ile daha karmaşı modellerin kurulmasını, test edilmesini ve tahmin sonuçlarında; önemli sapmalara yol açan değişkenlerin sorun olmaktan çıkmasını sağlamaktadır. Böylece, elde edilen sonuçlar için, daha kesin ve kapsamlı tahmin ve yorumlar yapılabilmektedir (Çalışkan, 2009:124).

Araştırma da kullanılan veri seti, zaman ve yatay kesit verilerini birlikte içerdiğinden, çalışmada ekonometrik yöntem olarak panel veri analizi uygulanmıştır. Bağımlı ve bağımsız değişkenler arasındaki ekonometrik ilişkileri analiz etmek için kullanılan temel panel veri regresyon modeli basit bir biçimde aşağıdaki gibidir (Greene, 2002:285).

$$
y_{i t}=\alpha_{i}+\beta_{1} X_{1 i t}+\varepsilon_{\text {it }} \quad i=1,2, \ldots, N \quad t=1,2, \ldots, T
$$

Yukarıdaki denklemde i alt simgesi; yatay kesit boyutu, t alt simgesi; zaman serisi boyutunu, yit; bağımlı değişkenleri, X1it bağımsız değişkenleri, $\alpha$ i sabit kesişim katsayısını ve cit ise; hata terimini göstermektedir.

Arellano-Bond (1991) tarafından geliştirilen Genelleştirilmiş Momentler Metodu (GMM) sonuçlarının geçerliliği 2 farklı test ile gerçekleştirilebilir. Bunlardan ilki Sargan testi diğeri ise 1. ve 2. sira otokorelasyon testidir (İskenderoğlu, Karadeniz ve Atioğlu, 2012: 291311). Sargan testi, Dinamik Panel Veri (GMM) modelindeki değişkenlerin tam ve doğru olarak kullanılıp kullanılmadığını gösteren testtir. Arellano-Bond (1991) tarafından önerilen 1. ve 2. derece otokorelasyon testi olan Arellano-Bond (AB) testi ise birinci fark modelinin kalıntıları için "ikinci dereceden otokorelasyon yoktur" temel hipotezini sınamak ile aynı şeyi ifade etmektedir. Elde edilecek sonuçlara göre, 2. derece otokorelasyonun istatistiksel olarak anlamsız olması beklenmekte ve ikinci dereceden otokorelasyonu olmayan modeller uygun modeller olarak nitelendirilmektedir. (Tatoğlu, 2012:99-101). Ayrıca, Dinamik Panel Veri Modeli çalışmalarında model tahminlerinin doğru gerçekleştirilip gerçekleştirilmediği ise Wald testi ile ölçülmektedir (Roodman, 2006:1-44).

\subsection{Araştırmanın Modeli}

Çalışmada Bankacılık sektörü ve Sanayi sektörü üzerine ayrı ayrı uygulanan Panel veri analizinde kullanılan modeller ve modellerde yer alan değişkenlerin belirlenmesinde literatürden yararlanılmıştır. Literatürdeki çalışmalar ışığında her iki sektörde faaliyet gösteren firmaların kurumsal yönetim ilkelerine uyum dereceleri ile karlılık oranları arasındaki ekonometrik ilişkileri belirleyebilmek için oluşturulan modeller şu şekildedir:

Model 1. Aktif Karlılığı ile Kurumsal Yönetim İlkeleri Arasındaki İlişki

$$
\mathrm{ROA}_{\mathrm{it}-1}=\alpha_{\mathrm{it}}+\beta_{1} \mathrm{KY}_{1}+\beta_{2} \mathrm{KY}_{2}+\beta_{3} \mathrm{KY}_{3}+\beta_{4} \mathrm{KY}_{4}+\beta_{5} \mathrm{KY}_{5}+\mu_{i t}+\varepsilon_{i t}
$$


Model 2. Özsermaye Karlılığı ile Kurumsal Yönetim İlkeleri Arasındaki İlişki

$\mathrm{ROE}_{\mathrm{it}-1}=\alpha_{\mathrm{it}}+\beta_{1} \mathrm{KY}_{1}+\beta_{2} \mathrm{KY}_{2}+\beta_{3} \mathrm{KY}_{3}+\beta_{4} \mathrm{KY}_{4}+\beta_{5} \mathrm{KY}_{5}+\mu_{i t}+\varepsilon_{i t}$

Model 3. Hisse Başına Kar ile Kurumsal Yönetim İlkeleri Arasındaki İlişki

$\mathrm{HBK}_{\mathrm{it}-1}=\alpha_{\mathrm{it}}+\beta_{1} \mathrm{KY}_{1}+\beta_{2} \mathrm{KY}_{2}+\beta_{3} \mathrm{KY}_{3}+\beta_{4} \mathrm{KY}_{4}+\beta_{5} \mathrm{KY}_{5}+\mu_{i t}+\varepsilon_{i t}$

Model 4. Fiyat Kazanç Oranı ile Kurumsal Yönetim İlkeleri Arasındaki İlişki

$\mathrm{FKO}_{\mathrm{it}-1}=\alpha_{\mathrm{it}}+\beta_{1} \mathrm{KY}_{1}+\beta_{2} \mathrm{KY}_{2}+\beta_{3} \mathrm{KY}_{3}+\beta_{4} \mathrm{KY}_{4}+\beta_{5} \mathrm{KY}_{5}+\mu_{i t}+\varepsilon_{i t}$

Model de bağımlı değişken olarak firmalara ait karlılık oranları kullanılmış olup, bağımlı değişkenler aşağıda açıklanmaktadır.

Modelde kullanılan bağımlı değişkenlerden biri Aktif Karlılı̆̆ı (ROA) dır. ROA verileri, KAP ta yer alan firmalara ait finansal tablolardan elde edilerek oran analizi ile hesaplanmıştır.

\section{Aktif Karlılık Oranı $=$ Net Kar $/$ Toplam Aktif}

Modelde kullanılan bağımlı değişkenlerden biri, Özsermaye Karlılı̆̆ı (ROE) dir. ROE verileri, KAP ta yer alan firmalara ait finansal tablolardan elde edilerek oran analizi ile hesaplanmıştır.

\section{Özsermaye Karlılığ 1 = Net Kar / Özsermaye}

Modelde kullanılan bağımlı değişkenlerden biri Hisse Başına Kar (HBK) dır. HBK verileri, KAP ta yer alan firmalara ait finansal tablolardan elde edilmiştir.

Modelde kullanılan bağımlı değişkenlerden bir diğeri ise; Fiyat Kazanç Oranı (FKO)' dır. FKO verileri, KAP ta yer alan firmalara ait finansal tablolardan elde edilerek oran analizi ile hesaplanmıştır.

Fiyat Kazanç Oranı $=$ Net Kar $/$ Faaliyet Karı

Model de kullanılan bağımlı değişkenlerin tümünün gecikmeli değerleri alınarak, analize dahil edilmiştir.

Araştırmada kullanılan, firmalara ait kurumsal yönetim ilkelerine uyum dereceleri olan ve Türkiye Kurumsal Yönetim Derneği (TKYD) web sitesinden temin edilen bağımsız değişkenler ise aşağıda açıklanmaktadır.

$\mathrm{KY}_{1=}$ Kurumsal Yönetim Derecelendirme Puanı KY $\mathrm{K}_{2}$ Hesap Verilebilirlik Puanı

$\mathrm{KY}_{3=}$ Şeffaflık Puanı $\mathrm{KY}_{4}=$ Eşitlik Puanı $\mathrm{KY}_{5=}$ Sorumluluk Puanı 


\section{BULGULAR}

Modellerin çalışması sonucunda ortaya çıkan sonuçlar sırasıyla; Bankacılık ve Sanayi Sektörü için ayrı ayrı, tanımlayıcı istatistiklerin yorumlanması, değişkenler arası ilişkilerin yorumlanması ve model uygulamasına ait ana regresyon sonuçları olmak üzere üç ayrı başlıkta değerlendirilmiştir.

\subsection{Bankacılık Sektörü Tanımlayıcı İstatistikler}

Modeldeki değişkenlere ait tanımlayıcı istatistikler Tablo 1’ de verilmektedir.

Tablo 1. Değişkenlere Ait Tanımlayıcı İstatistikler

\begin{tabular}{|c|c|c|c|c|c|}
\hline DEĞIŞKENLER & $\begin{array}{c}\text { GÖZLEM } \\
\text { SAYISI }\end{array}$ & ORTALAMA & $\begin{array}{c}\text { STANDART } \\
\text { SAPMA }\end{array}$ & MİN. DEĞER & $\begin{array}{c}\text { MAX. } \\
\text { DEĞER }\end{array}$ \\
\hline ROA & 160 & 0.008 & 0.008 & -0.024 & 0.041 \\
\hline ROE & 160 & 0.083 & 0.116 & -0.398 & 1.153 \\
\hline HBK & 160 & 0.076 & 0.119 & -0.675 & 0.42 \\
\hline FKO & 160 & 0.682 & 3.164 & -0.407 & 39.058 \\
\hline KY1 & 160 & 9.057 & 0.397 & 8.14 & 9.62 \\
\hline KY2 & 160 & 8.997 & 0.570 & 7.46 & 9.78 \\
\hline KY3 & 160 & 9.249 & 0.318 & 8.57 & 9.79 \\
\hline KY4 & 160 & 9.368 & 0.549 & 8.04 & 9.95 \\
\hline KY5 & 160 & 8.690 & 0.607 & 7.62 & 9.5 \\
\hline
\end{tabular}

Tablo 1' de özetlenen tanımlayıcı istatistik sonuçlarına göre, en yüksek standart sapmaya sahip olan değişkenin, bağımlı değişken olan Fiyat Kazanç Oranı (FKO), en düşük standart sapmanın elde edildiği değişkenin ise, yine bağımlı değişken olan Aktif Karlılık Oranı (ROA) olduğu görülmektedir.

\subsection{Bankacılık Sektörü Değişkenler Arasındaki İlişkilerin Yorumlanması}

Modeldeki bağımlı değişkenleri açıklayan değişkenler arasındaki korelasyon matrisi Tablo 2' de gösterilmiştir.

Tablo 2. Değişkenler Arasındaki İlişki

\begin{tabular}{|c|c|c|c|c|c|c|c|c|c|}
\hline & ROA & ROE & HBK & FKO & KY1 & KY2 & KY3 & KY4 & KY5 \\
\hline ROA & 10000 & & & & & & & & \\
\hline ROE & 0.6440 & 10000 & & & & & & & \\
\hline HBK & 0.5620 & 0.4558 & 10000 & & & & & & \\
\hline FKO & 0.3380 & 0.3060 & 0.1416 & 10000 & & & & & \\
\hline KY1 & -0.1028 & -0.2851 & -0.2205 & -0.1017 & 10000 & & & & \\
\hline KY2 & -0.1940 & -0.3278 & -0.3134 & -0.0923 & 0.9210 & 10000 & & & \\
\hline KY3 & 0.1638 & -0.0648 & 0.1021 & -0.0356 & 0.6529 & 0.3903 & 10000 & & \\
\hline KY4 & -0.2097 & -0.2837 & -0.3442 & -0.1505 & 0.8178 & 0.7452 & 0.5526 & 10000 & \\
\hline KY5 & -0.1966 & -0.2414 & -0.1250 & -0.0335 & 0.8689 & 0.8270 & 0.4341 & 0.4816 & 10000 \\
\hline
\end{tabular}


Tablo 2 incelendiğinde model de bağımlı değişkenlerden olan ROA ve HBK ile bağımsız değişkenlerden KY1,KY2,KY4 ve KY5 ile arasında negatif ilişki, KY3 ile arasında ise pozitif bir ilişki tespit edilmiştir. Bağımlı değişkenlerden ROE ve FKO ile tüm bağımsız değişkenler arasında ise negatif bir ilişki tespit edilmiştir.

\subsection{Bankacılık Sektörü Model Uygulamasına Ait Ana Regresyon Sonuçları}

2010-2019 yılları arasında Bankacılık sektöründe faaliyet gösteren şirketlerin Kurumsal Yönetim İlkelerine Uyum Dereceleri ile Karlılık Oranları arasındaki ilişkilerin tespit edilmesi için oluşturulan modellerin panel veri analizi ile test edilmesiyle elde edilen sonuçlar Tablo 3’ te gösterilmiştir.

Tablo 3. Bankacılık Sektörü Panel Veri Sonuçları

\begin{tabular}{|c|c|c|c|c|}
\hline & $\begin{array}{c}\text { MODEL } 1 \\
\text { (ROA) } \\
\text { GMM }\end{array}$ & $\begin{array}{l}\text { MODEL } 2 \\
\text { (ROE) } \\
\text { GMM }\end{array}$ & $\begin{array}{c}\text { MODEL } 3 \\
\text { (HBK) } \\
\text { GMM }\end{array}$ & $\begin{array}{c}\text { MODEL } 4 \\
\text { (FKO) } \\
\text { GMM }\end{array}$ \\
\hline ROA & $\begin{array}{c}0.082 \\
(0.291) \\
\end{array}$ & & & \\
\hline ROE & & $\begin{array}{c}0.043 \\
(0.613)\end{array}$ & & \\
\hline HBK & & & $\begin{array}{c}0.302 \\
(0.001) \\
\end{array}$ & \\
\hline FKO & & & & $\begin{array}{c}0.040 \\
(0.625) \\
\end{array}$ \\
\hline $\mathrm{KY}_{1}$ & $\begin{array}{c}-0.030 \\
(0.030)^{* *}\end{array}$ & $\begin{array}{c}-0.314 \\
(0.196) \\
\end{array}$ & $\begin{array}{l}-0.549 \\
(0.756) \\
\end{array}$ & $\begin{array}{l}-11.531 \\
(0.122) \\
\end{array}$ \\
\hline $\mathrm{KY}_{2}$ & $\begin{array}{c}0.001 \\
(0.731) \\
\end{array}$ & $\begin{array}{c}0.012 \\
(0.852) \\
\end{array}$ & $\begin{array}{l}-0.0502 \\
(0.306) \\
\end{array}$ & $\begin{array}{c}2.354 \\
(0.253) \\
\end{array}$ \\
\hline $\mathrm{KY}_{3}$ & $\begin{array}{r}-0.0010 \\
(0.823) \\
\end{array}$ & $\begin{array}{r}-0.0384 \\
(0.633) \\
\end{array}$ & $\begin{array}{c}-0.131 \\
(0.027)^{* *}\end{array}$ & $\begin{array}{c}2.304 \\
(0.350) \\
\end{array}$ \\
\hline $\mathrm{KY}_{4}$ & $\begin{array}{l}0.0046 \\
(0.222) \\
\end{array}$ & $\begin{array}{l}0.0286 \\
(0.655) \\
\end{array}$ & $\begin{array}{l}0.0266 \\
(0.570) \\
\end{array}$ & $\begin{array}{c}0.030 \\
(0.876) \\
\end{array}$ \\
\hline $\mathrm{KY}_{5}$ & $\begin{array}{c}0.007 \\
(0.076)^{*}\end{array}$ & $\begin{array}{c}0.079 \\
(0.254) \\
\end{array}$ & $\begin{array}{c}0.0456 * * \\
(0.362) \\
\end{array}$ & $\begin{array}{c}3.247 \\
(0.128) \\
\end{array}$ \\
\hline Grup Sayıs1 & 4 & 4 & 4 & 4 \\
\hline Gözlem Sayıs1 & 152 & 152 & 152 & 152 \\
\hline Wald $\chi^{2}$ (prob) & 0.0000 & 0.0008 & 0.0000 & 0.6040 \\
\hline Sargan $\chi^{2}$ & $\begin{array}{c}156.85 \\
(0.1711) \\
\end{array}$ & $\begin{array}{c}90.22 \\
(0.9997) \\
\end{array}$ & $\begin{array}{c}169.01 \\
(0.0478) \\
\end{array}$ & $\begin{array}{c}145.74 \\
(0.3749) \\
\end{array}$ \\
\hline $\begin{array}{c}\text { AR(1) için } \\
\text { Arellano-Bond } \\
\text { Testi(p değeri) }\end{array}$ & $\begin{array}{c}-6.7064 \\
(0.0000)\end{array}$ & $\begin{array}{l}-7.5612 \\
(0.0000)\end{array}$ & $\begin{array}{c}-6.5007 \\
(0.0000)\end{array}$ & $\begin{array}{c}-8.3544 \\
(0.0000)\end{array}$ \\
\hline $\begin{array}{c}\text { AR(2) için } \\
\text { Arellano-Bond } \\
\text { Testi(p değeri) }\end{array}$ & $\begin{array}{c}-1.8791 \\
(0.0602)\end{array}$ & $\begin{array}{l}-0.9389 \\
(0.3478)\end{array}$ & $\begin{array}{l}-0.2705 \\
(0.7868)\end{array}$ & $\begin{array}{c}0.5981 \\
(0.5497)\end{array}$ \\
\hline
\end{tabular}


Çalışmada kullanılan 1, 2, 3 ve 4 nolu modellerin analizinde dinamik panel tahmin yöntemlerinden biri olan ve Arellano-Bond (1991) tarafından geliştirilen Genelleştirilmiş Momentler Metodu (GMM) yöntemi kullanılmıştır. Modellerin analizinde GMM yöntemi ile birlikte, modelde kullanılan değişkenlerin bir bütün olarak anlamlı olup olmadığını gösteren Wald testi, modelde kullanılan araç değişkenlerinin geçerli olup olmadığını gösteren Sargan testi ve modelde otokorelasyon sorunu olup olmadığını gösteren Arellano-Bond (AB) testi kullanılmıştır.

Tablo 3' e bakıldığında Wald testi sonucuna göre, açıklayıcı değişkenlerin birlikte bağımlı değişkeni açıklamada anlamlı olduğu, Sargan testi sonucunda, kullanılan araç değişkenlerinin geçerli olduğu yani modellerin uygun olduğu ve Arellano-Bond'un otokorelasyon testi sonucunda ise, birinci dereceden negatif otokorelasyon olduğu, fakat beklendiği gibi ikinci dereceden otokorelasyon’ un olmadığı görülmektedir.

Ekonometrik modellerin çalışmasıyla birlikte bağımlı değişkeni açıklayan 4 farklı model için aşağıdaki denklemler elde edilmiştir.

$$
\begin{aligned}
& \mathrm{ROA}_{\mathrm{it}-1}=0.082-0.0309 \mathrm{KY}_{1}+0.001 \mathrm{KY}_{2}-0.001 \mathrm{KY}_{3}+0.004 \mathrm{KY}_{4}+0.007 \mathrm{KY}_{5} \\
& \mathrm{ROE}_{\mathrm{it}-1}=0.043-0.314 \mathrm{KY}_{1}+0.012 \mathrm{KY}_{2}-0.038 \mathrm{KY}_{3}+0.028 \mathrm{KY}_{4}+0.079 \mathrm{KY}_{5} \\
& \mathrm{HBK}_{\mathrm{it}-1}=0.030-0.054 \mathrm{KY}_{1}-0.050 \mathrm{KY}_{2}-0.131 \mathrm{KY}_{3}+0.026 \mathrm{KY}_{4}+0.045 \mathrm{KY}_{5} \\
& \mathrm{FKO}_{\mathrm{it}-1}=0.040-11.531 \mathrm{KY}_{1}+2.354 \mathrm{KY}_{2}+2.304 \mathrm{KY}_{3}+0.301 \mathrm{KY}_{4}+3.247 \mathrm{KY}_{5}
\end{aligned}
$$

Modellerin çalıştırılması sonucunda, ROA ile KY5 arasında istatistiksel olarak \% 10 düzeyinde anlamlı ve pozitif bir ilişki, HBK ile KY5 arasında benzer şekilde istatistiksel olarak \% 5 düzeyinde anlamlı ve pozitif bir ilişki elde edilmiştir. ROA ile KY1 arasında istatistiksel olarak \%5 düzeyinde anlamlı ve negatif bir ilişki ve HBK ile KY3 arasında ise benzer şekilde \% 5 düzeyinde anlamlı ve negatif bir ilişi elde edilmiştir. Bunun yanında ROE ve FKO ile verileri kullanılan bankaların Kurumsal Yönetim İlkelerine Uyum Puanları arasında anlamlı bir ilişki elde edilememiştir.

Panel veri analiz sonuçlarına göre, bankaların kurumsal yönetim ilkelerinden olan Sorumluluk Puanlarındaki (KY5) artışın, bankaların Aktif Karlılıklarını (ROA) ve Hisse Başına Karlılıklarını (HBK) artırdığı görülmektedir. Elde edilen bu bulgular, Ghayad (2008), Cornett vd. (2009), Grove vd. (2011), Akhyar vd. (2011), Peni ve Vahamaa (2012), Onakoya vd. (2012), Fanta vd. (2013), Shungu vd. (2014), Naushed ve Malik (2015), Manini ve Abdillahi (2015), Gümüş vd. (2015), Kusuma ve Ayurmardani (2016), Nawaz (2017), bankacılık sektöründe faaliyet gösteren şirketlerin kurumsal yönetim ilkeleriyle firma karlılığ1 arasında elde ettikleri anlamlı ve pozitif yönlü ilişkiyi destekler niteliktedir.

Ancak; analiz sonuçlarında, bankaların Kurumsal Yönetim Puanlarındaki (KY1) artışın, Aktif Karlılıklarını (ROA) azalttığı, yine aynı şekilde Kurumsal Yönetim İlkelerinden Şeffaflık Puanlarındaki (KY3) artışın da, bankaların Hisse Başına Kar (HBK) oranlarını azalttığı sonucuna ulaşılmıştır. Elde edilen bu bulgular ise, Aebi (2008), Peni ve Vahamaa (2012), Shungu vd. (2014), tarafından; bankacılık sektöründe faaliyet gösteren şirketlerde, 
kurumsal yönetim ilkelerine uyum dereceleriyle, firma karlılıkları arasında negatif yönlü elde edilen bulguları destekler niteliktedir.

\subsection{Sanayi Sektörü Tanımlayıcı İstatistikler}

Modeldeki değişkenlere ait tanımlayıcı istatistikler Tablo 4' te verilmektedir.

Tablo 4. Değişkenlere Ait Tanımlayıcı İstatistikler

\begin{tabular}{|c|c|c|c|c|c|}
\hline DEĞiŞKENLER & $\begin{array}{c}\text { GÖZLEM } \\
\text { SAYISI }\end{array}$ & ORTALAMA & $\begin{array}{c}\text { STANDART } \\
\text { SAPMA }\end{array}$ & MIN. DEĞER & $\begin{array}{c}\text { MAX. } \\
\text { DEĞER }\end{array}$ \\
\hline ROA & 160 & 0.062 & 0.120 & -0.036 & 1.46 \\
\hline ROE & 160 & 0.171 & 0.155 & -0.657 & 0.551 \\
\hline HBK & 160 & 0.474 & 0.599 & -0.358 & 2.96 \\
\hline KKO & 160 & 0.697 & 2.563 & -29.29 & 11.24 \\
\hline KY1 & 160 & 9.063 & 0.349 & 8.3 & 9.58 \\
\hline KY2 & 160 & 8.77 & 0.532 & 8 & 9.54 \\
\hline KY3 & 160 & 9.32 & 0.222 & 8.95 & 9.87 \\
\hline KY4 & 160 & 9.71 & 0.206 & 9.24 & 9.95 \\
\hline KY5 & 160 & 8.59 & 0.969 & 6.42 & 9.47 \\
\hline
\end{tabular}

Tablo 4' te özetlenen tanımlayıcı istatistik sonuçlarına göre, en yüksek standart sapmaya sahip olan değişkenin, bağımlı değişken olan Fiyat Kazanç Oranı (FKO), en düşük standart sapmanın elde edildiği değişkenin ise, yine bağımlı değişken olan Aktif Karlılık Oranı (ROA) olduğu görülmektedir.

\subsection{Sanayi Sektörü Değişkenler Arasındaki İlişkilerin Yorumlanması}

Modeldeki bağımlı değişkenleri açıklayan değişkenler arasındaki korelasyon matrisi Tablo 5' te gösterilmiştir.

Tablo 5. Değişkenler Arasındaki İlişki

\begin{tabular}{|l|l|l|l|l|l|l|l|l|l|}
\hline & ROA & ROE & HBK & FKO & KY1 & KY2 & KY3 & KY4 & KY5 \\
\hline RO & 10000 & & & & & & & & \\
A & & & & & & & & & \\
\hline ROE & 0.354 & 10000 & & & & & & & \\
& 8 & & & & & & & & \\
KB & 0.001 & 0.263 & 10000 & & & & & & \\
\hline FK & 6 & 5 & & & & & & & \\
O & 0.068 & 0.404 & 0.221 & 10000 & & & & & \\
\hline KY1 & - & - & 0.309 & - & 10000 & & & & \\
& 0.2298 & 0.0422 & 1 & 0.0386 & & & & & \\
\hline KY2 & - & - & 0.129 & - & 0.617 & 10000 & & & \\
& 0.2684 & 0.2365 & 4 & 0.0802 & 4 & & & \\
\hline KY3 & - & - & 0.399 & 0.006 & 0.791 & 0.460 & 10000 & & \\
& 0.1551 & 0.0562 & 7 & 1 & 7 & 9 & & \\
\hline KY4 & - & 0.075 & 0.328 & - & 0.751 & 0.142 & 0.723 & 10000 & \\
& 0.0634 & 9 & 0 & 0.0172 & 3 & 8 & 1 & & \\
\hline KY5 & - & 0.048 & 0.285 & - & 0.886 & 0.254 & 0.654 & 0.814 & 1000 \\
& 0.1452 & 0 & 7 & 0.0099 & 9 & 5 & 6 & 0 & 0 \\
\hline
\end{tabular}


Tablo 5 incelendiğinde model de bağımlı değișkenlerden olan ROA ile bağımsız değişkenler arasında negatif bir ilişki, ROE ile bağımsız değişkenlerden KY1, KY2 ve KY3 arasında negatif, KY4 ve KY5 ile arasında pozitif bir ilişki tespit edilmiştir. Bağımlı değişkenlerden HBK ile bağımsız değişkenler arasında pozitif bir ilişki olduğu, bağımlı değişkenlerden FKO ile bağımsız değişkenlerden KY1, KY2, KY4 ve KY5 arasında negatif ve KY3 ile arasında ise pozitif bir ilişki tespit edilmiştir.

\subsection{Sanayi Sektörü Model Uygulamasına Ait Ana Regresyon Sonuçları}

2010-2019 y1lları arasında Sanayi sektöründe faaliyet gösteren şirketlerin Kurumsal Yönetim İlkelerine Uyum Dereceleri ile Karlılık Oranları arasındaki ilişkilerin tespit edilmesi için oluşturulan modellerin panel veri analizi ile test edilmesiyle elde edilen sonuçlar Tablo 6' da gösterilmiştir.

Tablo 6. Sanayi Sektörü Panel Veri Sonuçları

\begin{tabular}{|c|c|c|c|c|}
\hline & $\begin{array}{c}\text { MODEL } 1 \\
\text { (ROA) } \\
\text { GMM }\end{array}$ & $\begin{array}{l}\text { MODEL } 2 \\
\text { (ROE) } \\
\text { GMM }\end{array}$ & $\begin{array}{c}\text { MODEL } 3 \\
\text { (HBK) } \\
\text { GMM }\end{array}$ & $\begin{array}{l}\text { MODEL } 4 \\
\text { (FKO) } \\
\text { GMM }\end{array}$ \\
\hline ROA & $\begin{array}{l}-0.014 \\
(0.862)\end{array}$ & & & \\
\hline ROE & & $\begin{array}{c}0.250 \\
(0.002)^{* * *}\end{array}$ & & \\
\hline HBK & & & $\begin{array}{c}0.262 \\
(0.003)^{* * *}\end{array}$ & \\
\hline FKO & & & & $\begin{array}{l}-0.0936 \\
(0.262)\end{array}$ \\
\hline KY1 & $\begin{array}{l}-0.247 \\
(0.115)\end{array}$ & $\begin{array}{c}0.062 \\
(0.742)\end{array}$ & $\begin{array}{c}0.397 \\
(0.470)\end{array}$ & $\begin{array}{c}1.992 \\
(0.566)\end{array}$ \\
\hline KY2 & $\begin{array}{c}0.112 \\
(0.094)^{*}\end{array}$ & $\begin{array}{c}0.093 \\
(0.250)\end{array}$ & $\begin{array}{c}0.430 \\
(0.073)^{*}\end{array}$ & $\begin{array}{c}2.498 \\
(0.10)^{*}\end{array}$ \\
\hline KY3 & $\begin{array}{l}-0.060 \\
(0.595)\end{array}$ & $\begin{array}{l}-0.025 \\
(0.853)\end{array}$ & $\begin{array}{l}-0.313 \\
(0.435)\end{array}$ & $\begin{array}{l}-2.960 \\
(0.251)\end{array}$ \\
\hline KY4 & $\begin{array}{c}0.104 \\
(0.282)\end{array}$ & $\begin{array}{l}-0.078 \\
(0.507)\end{array}$ & $\begin{array}{c}0.608 \\
(0.081)^{*}\end{array}$ & $\begin{array}{l}-1.242 \\
(0.580)\end{array}$ \\
\hline KY5 & $\begin{array}{c}0.005 \\
(0.891)\end{array}$ & $\begin{array}{l}-0.038 \\
(0.450)\end{array}$ & $\begin{array}{l}-0.212 \\
(0.129)\end{array}$ & $\begin{array}{l}-0.795 \\
(0.377)\end{array}$ \\
\hline Grup Sayı1 & 4 & 4 & 4 & 4 \\
\hline Gözlem Sayıs1 & 152 & 152 & 152 & 152 \\
\hline Wald $\gamma^{2}$ (nrob) & 0.0033 & 0.0144 & 0.0000 & 0.4221 \\
\hline Sargan $\chi^{2}$ & $\begin{array}{c}122.98 \\
(0.8604)\end{array}$ & $\begin{array}{c}150.97 \\
(0.2676)\end{array}$ & $\begin{array}{c}152.46 \\
(0.2405)\end{array}$ & $\begin{array}{c}142.46 \\
(0.4496)\end{array}$ \\
\hline $\begin{array}{c}\text { AR(1) için } \\
\text { Arellano-Bond } \\
\text { Testi (p değeri) }\end{array}$ & $\begin{array}{l}-7.9699 \\
(0.0000)\end{array}$ & $\begin{array}{l}-6.5175 \\
(0.0000)\end{array}$ & $\begin{array}{l}-6.7913 \\
(0.0000)\end{array}$ & $\begin{array}{c}-8.7528 \\
(0.0000)\end{array}$ \\
\hline $\begin{array}{c}\text { AR(2) için } \\
\text { Arellano-Bond } \\
\text { Testi (p değeri) }\end{array}$ & $\begin{array}{l}-0.8645 \\
(0.3873)\end{array}$ & $\begin{array}{c}0.2653 \\
(0.7907)\end{array}$ & $\begin{array}{l}-0.0810 \\
(0.9354)\end{array}$ & $\begin{array}{l}-0.7331 \\
(0.4634)\end{array}$ \\
\hline
\end{tabular}


*, ** ve *** sırasıyla \%10, \%5 ve \%1 seviyesinde istatistiksel anlamlılığı ifade etmektedir. Parantez içindeki değerler p- anlamlılık değerleridir.

Çalışmada kullanılan 1, 2, 3 ve 4 nolu modellerin analizinde dinamik panel tahmin yöntemlerinden biri olan ve Arellano-Bond (1991) tarafından geliştirilen Genelleştirilmiş Momentler Metodu (GMM) yöntemi kullanılmıştır. Modellerin analizinde GMM yöntemi ile birlikte, modelde kullanılan değişkenlerin bir bütün olarak anlamlı olup olmadığını gösteren Wald testi, modelde kullanılan araç değişkenlerinin geçerli olup olmadığını gösteren Sargan testi ve modelde otokorelasyon sorunu olup olmadığını gösteren Arellano-Bond (AB) testi kullanılmıştır.

Tablo 6’ ya bakıldığında Wald testi sonucuna göre, açıklayıcı değişkenlerin birlikte bağımlı değişkeni açıklamada anlamlı olduğu, Sargan testi sonucunda, kullanılan araç değişkenlerinin geçerli olduğu yani modellerin uygun olduğu ve Arellano-Bond'un otokorelasyon testi sonucunda ise, birinci dereceden negatif otokorelasyon olduğu, fakat beklendiği gibi ikinci dereceden otokorelasyon’ un olmadığı görülmektedir.

Ekonometrik modellerin çalışmasıyla birlikte bağımlı değişkeni açıklayan 4 farklı model için aşağıdaki denklemler elde edilmiştir.

$$
\begin{aligned}
& \mathrm{ROA}_{\mathrm{it}-1}=-0.014-0.247 \mathrm{KY}_{1}+0.112 \mathrm{KY}_{2}-0.060 \mathrm{KY}_{3}+0.104 \mathrm{KY}_{4}+0.005 \mathrm{KY}_{5} \\
& \mathrm{ROE}_{\mathrm{it}-1}=0.250+0.062 \mathrm{KY}_{1}+0.093 \mathrm{KY}_{2}-0.025 \mathrm{KY}_{3}-0.078 \mathrm{KY}_{4}-0.036 \mathrm{KY}_{5} \\
& \mathrm{HBK}_{\mathrm{it}-1}=0.262+0.397 \mathrm{KY}_{1}+0.430 \mathrm{KY}_{2}-0.313 \mathrm{KY}_{3}+0.608 \mathrm{KY}_{4}-0.212 \mathrm{KY}_{5} \\
& \mathrm{FKO}_{\mathrm{it}-1}=-0.093+1.992 \mathrm{KY}_{1}+2.498 \mathrm{KY}_{2}-2.960 \mathrm{KY}_{3}-1.242 \mathrm{KY}_{4}-0.795 \mathrm{KY}_{5}
\end{aligned}
$$

Modellerin çalıştırılması sonucunda, ROA ile KY2 arasında istatistiksel olarak \% 10 düzeyinde anlamlı ve pozitif bir ilişki, HBK ile KY2 ve KY4 arasında benzer şekilde istatistiksel olarak \% 10 düzeyinde anlamlı ve pozitif bir ilişki elde edilmiştir. Yine bağımlı değişkenlerden FKO ile KY2 arasında ise, benzer şekilde istatistiksel olarak \% 10 düzeyinde anlamlı ve pozitif bir ilişki olduğu sonucuna ulaşılmıştır.

Bunun yanında ROE nin bağımlı değişken olarak kullanıldığı modelde ise; ROE ile Sanayi sektöründe faaliyet gösteren firmaların Kurumsal Yönetim İlkelerine Uyum Puanları arasında anlamlı bir ilişki elde edilememiştir.

Panel veri analiz sonuçlarına göre, sanayi firmalarının kurumsal yönetim ilkelerinden olan Hesap Verilebilirlik Puanlarındaki (KY2) artışın, sanayi firmalarının Aktif Karlılıklarını (ROA), Hisse Başına Karlılıklarını (HBK) ve Fiyat Kazanç Oranlarını (FKO) artırdığı görülmektedir. Aynı şekilde, kurumsal yönetim ilkelerinden olan Eşitlik Puanlarındaki (KY4) artışın da, firmaların Hisse Başına Kar (HBK) Oranlarını artırdığı sonucuna ulaşılmıştır. Elde edilen bu bulgular, Haddad vd. (2011), Acaravcı vd. (2015), Kayalı ve Doğan (2018), sanayi sektöründe faaliyet gösteren şirketlerin kurumsal yönetim ilkeleriyle firma karlılığı arasında elde ettikleri anlamlı ve pozitif yönlü ilişkiyi destekler niteliktedir. 


\section{DEĞERLENDIIRME VE SONUÇ}

Ulusal ve uluslararası piyasalarda meydana gelen finansal krizler, küresel rekabet ortamlarında varlıklarını sürdürebilmek için ticari faaliyet gösteren firmalar açısından olumsuz sonuçlar doğurabilen unsurlardır. Bu kriz dönemlerinde ve sıkıntılı ekonomik süreçlerde, firmaların; etkili bir rekabet gücü sergileyebilmelerinin temel unsurlarından biri; kurumsal yönetim ilkelerine uyum düzeyleridir. Günümüzde önemi giderek artan, kurumsal yönetim uygulamaları; yöneticilere, daha sağlam bir zeminde, daha sağlıklı ve başarılı bir yönetim sağlamakla birlikte, gerçek dışı yayınlanan finansal veriler gibi, manipülasyonlar sonucu meydana gelen şirket skandalları neticesinde, zedelenen yatırımcı güveninin de yeniden inşa edilmesine olanak sağlamaktadır.

Son yıllarda, çeşitli sektörlerde faaliyet gösteren firmalar tarafindan artarak uygulamaya konulan kurumsal yönetim, ülkemizde, 2007 yılında Kurumsal Yönetim Endeksi (XKURY) olarak Borsa İstanbul çatısı altında hesaplanmaya başlanmıştır. Türkiye de halen bu endekste 51 şirket işlem görmektedir. Kurumsal Yönetim Endeksinde yer alan şirketlerin, belirli periyotlarda yayınlanan kurumsal yönetim ilkelerine ait başarı puanları, yatırımcılar açısından, alacakları yatırım kararlarında yol gösterici olması beklenmektedir. Dolayısıyla, kurumsal yönetim endeksine dahil olan şirketlerde, finansal karlılık oranlarının artacağı düşünülmektedir.

Bu bağlamda, çalışmanın amacı; BIST (XKURY) endeksinde işlem gören, bankacılık ve sanayi sektöründe faaliyet gösteren firmalara ait kurumsal yönetim puanları ile firma karlılıkları arasındaki ilişkileri ayrı ayrı ölçmek ve kıyaslamaktır. Araştırma, 2010-2019 yılları arasındaki 10 yıllık süreyi kapsamaktadır. İlgili dönemlerde, Kamuoyu Aydınlatma Platformu (KAP) ve Türkiye Kurumsal Yönetim Derneği (TKYD)' den elde edilen, bankalara ve sanayi firmalarına ait 3' er aylık finansal veriler, panel veri analiz yöntemi kullanılarak test edilmiştir.

Bankacılık sektöründe uygulanan panel veri analizi ile kurumsal yönetim ilkelerinden olan Sorumluluk Puanlarındaki artışın, bankaların Aktif Karlılıklarını ve Hisse Başına Karlılıklarını artırdığı, ancak; Kurumsal Yönetim Puanlarındaki artışın, Aktif Karlılıklarını azalttığı, yine aynı şekilde Kurumsal Yönetim İlkelerinden Şeffaflık Puanlarındaki artışın da, bankaların Hisse Başına Kar oranlarını azalttığı sonucuna ulaşılmıştır.

Sanayi sektöründe uygulanan panel veri analizi ile ise; kurumsal yönetim ilkelerinden olan Hesap Verilebilirlik Puanlarındaki artışın, sanayi firmalarının Aktif Karlılıklarını, Hisse Başına Karlılıklarını ve Fiyat Kazanç Oranlarını artırdığı görülmektedir. Aynı şekilde, kurumsal yönetim ilkelerinden olan Eşitlik Puanlarındaki artışın da, firmaların Hisse Başına Kar oranlarını artırdı̆̆ sonucuna ulaşılmıştır.

Ampirik sonuçlar, sanayi sektöründe uygulanan kurumsal yönetim ilkelerinin, bankacılık sektörüne göre, karlılık oranları üzerinde daha anlamlı sonuçlar verdiğini ve istatistiksel olarak daha güçlü bir ilişki olduğunu göstermektedir. Bu durum, bankacilık sektöründe faaliyet gösteren şirketlerin; kurumsal yönetim uygulamalarından ziyade, ülkemiz içerisinde, Bankacılık Düzenleme ve Denetleme Kurumu (BDDK) ile uluslararası kredi 
derecelendirme kuruluşları gibi kurumlar tarafından çok ciddi düzenlemelere tabi tutulmaları ve bu doğrultuda yönetilmediklerinde ciddi yaptırımlara maruz kalmaları ile açıklanabilir.

\section{KAYNAKLAR}

Acaravcı Kakilli, Songül - Kandır, Serkan Y - Zelka, Ahmet (2015), “Kurumsal Yönetimin BIST Şirketlerinin Performanslarına Etkisinin Araştırılması”, Niğde Üniversitesi İ.İ.B.F. Dergisi, 2015, 8(1), ss.171-183.

Aebi, Vincent - Sabato, Gabriele - Markus, Schmid (2012), “Risk Management, Corporate Governance, and Bank Performance’’, Journal of Banking \& Finance, 36(1), pp. 32133226.

Ahmed, Sarwar U. - Ullah, Wali - Ahmed, Samiul Parvez - Rahman, Ashikur (2016), “An Empirical Study on Corporate Governance and Islamic Bank Performance: A Case Study of Bangladesh’, Journal of Finance \& Banking Studies, 5(4), pp. 103-116.

Akhyar, Muhammed - Majdi, Rashid - Kameel, Meera, - Sheila, Nu Nu Htay (2011), “A panel data analysis on the relationship between corporate governance and bank efficiency. Paper presented in the Global Accounting Finance and Economics Conference’’, Monash University, Melbourne Australia.

Al-Haddad, Waseem - Alzurgan, Saleh T. - Al - Sufy Fares J. (2011), “The Effect Of Corporate Governance on The Performance of Jordanian Industrial Companies: An Empirical Study on Amman Stock Exchange”, International Journal Of Humanities And Social Science,1(4), pp.55-69.

Arıkan, Naci (2008), “ABD Finans Piyasasında Yaşanan Son Kriz Ve ABD Yönetiminin Krizden Çıkma Planları”, Vergi Dünyası Dergisi, 28 (326).

Arouri, Houdi - Hossain, Mohammed - Muttakin, M. Badrul (2011), “Ownership Structure, Corporate Governance and Bank Performance: Evidence From GCC Countries”, Corporate Ownership and Control, 8(4), pp. 365-372.

Arun, Thankom - Turner, John J.D. (2014), “Corporate Governance of Banks in Developing Economies: Concepts and Issues”, Corporate Governance, 12(3), pp.371.

Aygün, Mehmet - İç, Süleyman (2010), “Genel Müdürün Aynı Zamanda Yönetim Kurulu Üyesi Olması Firma Performansını Etkiler mi?’’, Muhasebe ve Finansman Dergisi, 47.

Bank for International Settlements (2006), "Enhancing Corporate Governance For Banking Organisations", Basel Committee on Banking Supervision, February 2006. 
Beycan, Mehmet (2013), “Kurumsal Yönetim ve Türk Bankacılık Sektörü Üzerine Etkileri”, Dokuz Eylül Üniversitesi SBE Doktora Tezi, İzmir.

Bukair, A. Awadh - Rahman, Azhar Abdul (2015), “Bank Performance and Board of Directors Attributes by Islamic Banks”, International Journal of Islamic and Middle Eastern Finance and Management, 8(3), pp. 291-309.

Caprio, Gerard - Levine, Ross (2002), “Corporate Governance of Banks: Concepts and International Observations”, Global Corporate Governance Forum Research Network Meeting.

Chang, Chen Shan - Yu, Shang Wu - Hung, Cheng Huang (2015), “Firm Risk and Performance: the Role of Corporate Governance’, Review of Manageria Science, 9(1), pp.141-173.

Cornet, Marcio M - McNutt, Jamie - Tehranian, Hassan (2009), “'Corporate Governance and Earnings Management at Larfe U.S. Bank Holding Companies”, Journal of Corporate Finance, 15, pp.412-430.

Çalışkan, Zafer (2009), “OECD Ülkelerinde Sağlık Harcamaları: Panel Veri Analizi”, Erciyes Üniversitesi İktisadi ve İdari Bilimler Fakültesi Dergisi, 34, ss.117-137.

Dağl1, Hüseyin - Ayaydın, Hasan - Eyüboğlu, Kemal (2010), “Kurumsal yönetim endeksi performans değerlendirmesi: Türkiye örneği”, Muhasebe ve Finansman Dergisi, 48.

Davies, Adrian (2006), “Best Practice in Corporate Governance Building Reputation and Sustainable Success, USA and UK: Gower Publishing Company.

Dinçer, Banu - Dinçer, Caner (2013), “Corporate Governance and Market Value: Evidence From Turkish Banks”, International Journal Of Academic Research in Business and Social Sciences, 3(1), ss. 241-249.

Ertuna, Bengi - Tükel, Ali (2008), "Şirketlerin Kamuyu Aydınlatma Düzeyleri: Ortaklık Yapısı ve Kurumsal Yönetimin Etkileri", İMKB Dergisi, 10(40), ss.7-37.

Fanta, Ashenafi - Kemal, Kelifa - Waka, Yodit Kassa (2013), “Corporate Governance and impact on Bank Performance’, Journal of Finance and Accounting, 1(1), pp. 19-26.

Ghayad, Racha (2008), Corporate Governance and The Global Performance of Islamic Banks Humanomics, 24(3), pp. 207-216.

Grene, William H. (2002), Econometric analysis, New York: Prentice Hall.

Grove, Hugh - Patelli, Lorenzo - Victoravich, Lisa M - Xu, Pisun (2011), “Corporate Governance and Performance in the Wake of the Financial Crisis: Evidence from US Commercial Banks', Corporate Governance: An International Review, 19(5), pp. 418436. 
Gümüş, Gülüzar Kurt - Gümüş, Yusuf - Altunal, Işık (2017), “Bankacılık Sektöründe Kurumsal Yönetim ve Finansal Performans İlişkisi: Türkiye ve Kazakistan Örneği’, Kastamonu Üniversitesi İktisadi ve İdari Bilimler Fakültesi Dergisi, 16(2), ss. 104121.

Gürbüz, Osman - Ergincan, Yakup (2004), “Kurumsal Yönetim Türkiye'deki Durumu ve Geliştirilmesine Yönelik Öneriler’’, Literatür Yayıncılık, İstanbul.

İskenderoğlu, Ömer - Karadeniz, Erdinç - Atioğlu, Eyüp (2012), “Türk Bankacılık Sektöründe Büyüme, Büyüklük ve Sermaye Yapısı Kararlarının Karlılığa Etkisinin Analizi”, Eskişehir Osmangazi Üniversitesi İİBF Dergisi, 7(1), ss.291-311.

Januszewski, Silke - Köke, Jens - Winter, Joachim (1999), "Product Market Competition, Corporate Governance and Firm Performance: An Empirical Analysis for Germany", ZEW Discussion Papers, pp. 63-99.

Kandır, Serkan Yılmaz (2013), "Kurumsal Yönetim Derecelendirme Notu Açıklamalarının Hisse Senedi Getirileri Üzerindeki Etkisinin İncelenmesi”, Bankacilar Dergisi, 85, ss.21-31.

Karluk, S. Rıdvan (2002), “Türkiye Ekonomisi, Tarihsel Gelişim”, Yapısal ve Sosyal Değişim, 7, İstanbul.

Kayalı, Nilgün - Doğan, İrem (2018), "Kurumsal Yönetim Derecelendirme Notu İle İşletmelerin Finansal Başarıları Arasındaki İlişskinin İncelenmesi”, Muhasebe ve Finansman Dergisi, ss.111-123.

Koç, Erdem - Şenel, Mahmut Can - Kaya, Kadir (2018), “Türkiye de Sanayi Sektörünün Genel Durumu, Sanayi Ciro Endeksi’’, Mühendis ve Makine, 59(697), ss. 17-34.

Kula, Veysel - Baykut Ender (2013), "Kurumsal Yönetim Endeksinde Yer Almanın Mevduat Bankalarının Performansına Etkisi: BIST Örneği”, Sosyal Bilimler Dergisi, 15(2), ss.121-136.

Kusuma, Hadri - Ayumardani, Ariza (2016), “The Corporate Governance Efficiency and Islamic Performance: An Indonesian Evidence”, Polish Journal of Management Studies, 13(11), pp.111-120.

Lee, Siew Peng - Isa, Mansur (2015), “Directors' Remuneration, Governance and Performance: The Case of Malaysian Banks’’. Managerial Finance, 41(1), pp.26-44.

Lin Chen - Ma, Yue - Su, Dongwei (2009), “Corporate Governance and Firm Efficiency: Evidence from China's Publicly Listed Firms", Managerial and Decision Economics, 30 (3), pp.193-209. 
Manini, Muganda Munir - Abdillahi, U. Ali (2015), “Corporate Governance Mechanisms and Financial Performance of Commercial Banks in Kenya”, Journal of Business and Management, 17(3), pp. 25-40.

Memiş, M. Ünsal - Çetenak, E. Hüseyin (2012), "Kurumsal Yönetimin Kazanç Yönetimi Uygulamaları Üzerine Etkisi: İMKB'de İşlem Gören Şirketler Üzerine Uygulama”, Çukurova Üniversitesi Sosyal Bilimler Enstitüsü Dergisi, 21(3), ss.205-224.

Naushad, Mohammad - Malik, Syed Abdul (2015), "Corporate Governance and Bank Performance: A Study of Selected Banks in GCC Region”, Asian Social Science, 11(9), pp. 226-234.

Nawaz, Tasawar (2017), “Momentum Investment Strategies, Corporate Governance and Firm Performance: An Analysisof Islamic Banks’', Corporate Governance, 17(2), pp.192211.

Onakoya, Adegbemi - Ofoegbu, Donald - Fasanya, Ismail - Ismail, O. (2012), "Corporate Governance and Bank Performance: A Pooled Study of Selected Banks in Nigeria", European Scientific Journal, 8(28), pp. 155-164.

Paslı, Ali (2008), “'Anonim Ortaklık Kurumsal Yönetimi’’, İstanbul, Beta Yayınları.

Peni, Emilia - Vähämaa, Sami (2012), “Did Good Corporate Governance Improve Bank Performance during the Financial Crisis?" Journal of Financial Services Research, 41(1), pp. 19-35.

Roodman, David (2006), "How to Do xtabond2: An Introduction to Difference and System GMM in Stata”, Center For Global Development Working Paper No: 103, 1-44.

Shleifer, Andrei - Vishny, Robert W. (1997), "A Survey of Corporate Governance", The Journal of Finance, 52, (2), pp. 737 -783.

Shungu, Progress - Ngirande, Hlanganipai - Ndlovu, Godfrey (2014), “Impact of Corporate Governance on the Performance of Commercial Banks in Zimbabwe’', Mediterranean Journal of Social Sciences, 5(15), pp. 93-105.

Sloan, Richard G. (2001), "Financial accounting and corporate governance: a discussion”, The Journal of Finance, 32.

Sönmez, Asuman - Toksoy, Andaç (2011), “Kurumsal Yönetim İlkelerinin Türkiye’deki Aile Şirketlerinde Uygulanabilirliği”, , Maliye Finans Yazıları, 92, ss.51-90.

Tanrı̈ven, Cihan - Başçı, Savaş - Küçükkaplan, İlhan (2006), “Kurumsal yönetim açısından sahiplik ve kontrol yapısı ile üst düzey yönetici durumunun İMKB de faaliyet gösteren bankalarda incelenmesi’’, İşletme İktisat Finans Dergisi, 241, ss. 87-104. 
Tatoğlu, Ferda Yerdelen (2012), “İleri Panel Veri Analizi”, 1. Bask1, İstanbul: Beta Yayınları, ss. 99-101.

Topaç, Erhan (2002), “'Kurumsal Yönetim İlkelerinin Sermaye Piyasalarının Gelişmesindeki Önemi ve Türkiye Uygulamaları’, İMKB-Sermaye Piyasalarında Kurumsal Yönetim İlkeleri Konferans1, İstanbul.

Tunç, Tülin (2007), “Üretkenlik-İstihdam İlişkisi: Türkiye İmalat Sanayi Üzerine Bir Uygulama”, Mersin Üniversitesi, Yayınlanmamış Yüksek Lisans Tezi.

Turan, Ülkü - Bayyurt, Nizamettin (2013), “Kurumsal Yönetim, Mülkiyet Yapısı ve Performans”, Finans Politik \& Ekonomik Yorumlar, 50 (585).

Türkiye Kurumsal Yönetim Derneği (TKYD), tkyd. org. Erişim: 12.07.2020 TÜSİAD, 'Türkiye Sanayii' ne Sektörel Bakış’, İstanbul, 2008

Uyar, Süleyman (2004), “Kurumsal Şeffaflığın Sağlanmasında Kurumsal Anlayışının Önemi, Mali”, Çözüm Dergisi 66, İSMMMO Yayınları, İstanbul.

Woldridge Jeffrey M. (2009), Introductory Econometrics A Modern Approach, 4nd ed. USA: South-Western Cengage Learning.

Yenice, Sedat - Dölen, Tuğba (2013), “'IMKB’de İşlem Gören Firmaların Kurumsal Yönetim İlkelerine Uyumunun Firma Değeri Üzerindeki Etkisi”, Uluslararası Yönetim İktisat ve İşletme Dergisi, 9(19).

Yıldırım, Mehmet (2007), “Türkiye’de Kurumsal Yönetim ve Şirketlerin Finansal Performansları Üzerine Etkileri”, (Basılmamış Doktora Tezi), Dokuz Eylül Üniversitesi Sosyal Bilimler Enstitüsü.

Zelka, Ahmet (2014), "Kurumsal Yönetimin Firma Performansı Üzerine Etkisi: Türkiye Uygulaması”, Mustafa Kemal Üniversitesi, (Yayınlanmamış Yüksek Lisans Tezi). 
